\title{
Influence of Various Carbon Sources on Growth and Biomass Accumulation of Some Lactic Acid Bacteria Strains
}

\author{
STEFANA PETRUT'1,2, ELENA RUSU²*, IOAN SORIN TUDORACHE², DIANA PELINESCU ${ }^{1}$, IONELA SARBU ${ }^{1}$, ILEANA STOICA ${ }^{1}$, \\ TATIANA VASSU ${ }^{1}$ \\ 'University of Bucharest, Faculty of Biology, Department of Genetics, 1-3 Portocalelor Alley, 60101, Bucharest, Romania \\ 2Titu Maiorescu University, Faculty of Medicine, Preclinic Department, 67A Gheorghe Petrascu Str., 031593, Bucharest,Romania
}

\begin{abstract}
Lactic acid bacteria ( $L A B)$ are among the most important group of bacteria, with a critical role in food, pharmaceutical and medical industry. The fast-growing characteristics of $L A B$ strains, their metabolic activity associated with production of many beneficial compounds and most of all, their GRAS status (Generally Recognized As Safe) recommends them as starter cultures for food biotechnology processes. During last decades, $L A B$ strains have also an extensive prophylactic or therapeutic use as probiotics. Due to the fact that there are current limitations in the use of standard MRS media (de Man Rogosa Sharpe), which is selective especially for lactobacilli and enterococci, the aim of the present study was to optimize the growth medium composition for isolating a wide range of $L A B$ strains with biotechnological potential and to improve the biomass accumulation. For this purpose, it has been evaluated the growth of Lactobacillus (L.) rhamnosus ATCC $^{\circledR} 9595^{\text {TM }}$, Streptococcus (S.) salivarius subsp. thermophilus ATCC ${ }^{\circledR} 19258^{\text {TM }}$, Pediococcus (P.) acidilactici ATCC ${ }^{\circledR} 8042^{\text {TM }}$, Lactococcus (L.) lactis 28 and Enterococcus (E.) faecium FFb CMGB L-18 on MRS broth with various carbon sources (glucose, lactose, galactose, maltose, mannose, ribose, arabinose, sucrose, fructose). The results of the study showed that there are interesting differences in the requirements of each analyzed species. The optimization of standard medium composition will be very useful for grow th studies as well as metabolic flux studies.
\end{abstract}

Keywords: lactic acid bacteria, $L A B$, carbon sources

$L A B$ are among the most important group of microorganisms providing health benefits to human, animal and plants and has been used in food fermentation from ancient times [1].

They are defined as a group of fastidious nutritional requirements microorganisms, Gram-positive, nonsporing rods and cocci, anaerobic, but aerotolerant bacteria, which produce lactic acid as the major end-product of carbohydrates fermentation [2,3]. Lactic acid has numerous technological applications, being used as a preservation and flavor-enhancing agent in food industry, as an emulsifying and moisturizing agent in cosmetics products and also, as an intermediate in pharmaceutical processes or in the synthesis of optically pure pharmaceuticals $[4,5]$.

The most important genera of $L A B$ group are Lactobacillus, Lactococcus, Enterococcus, Streptococcus, Pediococcus, Leuconostoc and Bifidobacterium, the lastmentioned shares some physiological and biochemical properties and also some of the ecological niches with LAB [6].

For food industry and biotechnological processes, metabolic activities of $L A B$,

optimal conditions for survival and growth are essential for any applications. Sensory properties, shelf-life, and safety of a majority of fermented foods are determined by the metabolic activity of food fermenting $L A B$. The metabolism of these microorganisms, a relatively simple carbon and energy metabolism, is influenced by the environmental conditions $[7,8]$.

Most data required so far have revealed that $L A B$ is a group which exhibits an enormous capacity to degrade different carbohydrates; this feature allows them to adapt to various conditions and change their metabolism accordingly, being able to colonize different ecological niches. Carbohydrates are considered the main source of energy for bacterial growth, being metabolized by LAB strains into different useful compounds $[9,10]$.

The mode of glucose fermentation under standard conditions divide $L A B$ species into two groups: the homofermentative converting glucose almost quantitatively to lactic acid and the heterofermentative, fermenting glucose to lactic acid, ethanol/acetic acid, and $\mathrm{CO}_{2}[9]$.

$L^{2} A B$ strains are usually used as starter cultures for the production of fermented foods (cheese, yoghurt, sourdough, dry sausage s.o.) or for their aromatic compounds biosynthesized during the fermentations which have industrial importance, especially in and the development of the organoleptic properties, texture or flavor of differentfood products [11, 12]. Their preservative effect, due to the production of antimicrobial compoundssuch as organic acids, bacteriocins or hydrogen peroxide, contributes to shelf-life of the fermented foods by inhibition of growth and development of pathogenic bacteria [1317].

Optimization of an effective growth medium for growing LAB must be achieved, even if commercial media, such as MRS, are generally optimal, containing many elements like carbohydrates, amino acids, peptides, vitamins and $\mathrm{Mg} / \mathrm{Mn}$ salts which are required for growth. Sometime, due to the MRS standard medium limitations (selective especially for lactobacilli and enterococci) it is necessary to use a different media for wide range microorganism's isolation and for biomass accumulation $[1,18]$.

The present work aimed to describe an optimized growth media formula in terms of carbon source for $L A B$ strains from various genera with biotechnological applications in food industry.

*email:elenarusu98@yahoo.com; Phone +40745036782 


\section{Experimental part}

Materials and ,ethods

Microbial strains and culture medium

The five lactic acid bacteria strains (3 type strains obtained from American Type Culture Collection: $L$. rhamnosus ATCC ${ }^{\otimes} 9595^{\mathrm{TM}}$, S. salivarius subsp. thermophilus ATCC $^{\circledR} 19258$, P. acidilactici ATCC ${ }^{\circledR} 8042^{\text {TM }}$ and 2 strains from MICROGEN Center collection, University of Bucharest: L. lactis 28 and E. faecium FFb CMGB L-18, characterized and identified by molecular tools in previous studies-data not shown) were maintained in MRS broth supplemented with $20 \%(\mathrm{v} / \mathrm{v})$ glycerol and stored at $-70^{\circ} \mathrm{C}$.

For further assays, each bacterial strain was sub-cultured $(1 \% \mathrm{v} / \mathrm{v})$ in MRS broth for $24 \mathrm{~h}$ at $37^{\circ} \mathrm{C}$.

The growth studies were performed on MRS medium without carbon source containing: $1 \%$ peptone, $0.5 \%$ meat extract, $0.5 \%$ yeast extract, $0.2 \%$ dipotassium hydrogen phosphate, $0.1 \%$ Tween $80,0.2 \%$ diammonium citrate, $0.5 \%$ sodium acetate trihydrate, $0.01 \%$ magnesium sulfate heptahydrate, $0.005 \%$ manganese sulfate tetrahydrate, $\mathrm{pH}=6.5-6.7 .2 \%$ of various carbon sources (glucose, lactose, fructose, galactose, sucrose, ribose, maltose, mannose, and arabinose) were added to this medium.

\section{Evaluation of growth on various carbon sources}

After two successive transfers of the analyzed strains in MRS broth (with $2 \%$ glucose) for $24 \mathrm{~h}$ at $37^{\circ} \mathrm{C}$, the activated cultures were centrifuged at $10.000 \mathrm{rpm}$ for 3 minutes and washed with distilled sterile water; the initial optical density (OD) of the cultures was measured at $600 \mathrm{~nm}$ $\left(\mathrm{OD}_{600 \mathrm{~nm}}\right)$ using a spectrophotometer (VilberLourmat) and finally diluted to obtain an $\mathrm{OD}_{\text {ono }}=1$ inoculum. This cell suspension was inoculated ( $1 \% \mathrm{~V} / \mathrm{V})$ in $10 \mathrm{~mL}$ MRS medium with a different carbon source, and incubated at $37^{\circ} \mathrm{C}$.

The growth of lactic acid bacteria strains in presence of mentioned carbon sources was determined by measuring the optical density at $600 \mathrm{~nm}$ in a Synergy HTX Multi-Mode Reader (Bio-Tek). Measurements of $O D$ values were carried outat $3 \mathrm{~h}$ interval over $48 \mathrm{~h}$ of incubation.

\section{Statistical analysis}

All growth tests results obtained were represented as bacterial growth curves and expressed as mean \pm SD ( $n$ = 3) using Excel tool from the Microsoft Office 2016 package.

\section{Results and discussions}

Growth studies assays on different carbon sources were performed in order to obtain a chemically improved medium for isolating a wide range of lactic acid bacteria microorganisms with biotechnological important properties. In order to achieve the main objective 5 reference strains belonging to the genera Lactobacillus, Lactococcus, Pediococcus, Streptococcus and Enterococcus were used.

The results of our study revealed differences between analyzed strains to growth on various carbon sources. Lactobacillus is the genus which includes the highest number of GRAS species; many of these having a great importance in food microbiology and human nutrition, but specific strains have been recognized as having probiotic properties [19].

As shown in figure 1, L. rhamnosus ATCC ${ }^{\circledR} 9595^{\mathrm{TM}}$ exhibit nutritional preference for galactose, utilization of this carbon source being attributed to a high galactokinase activity. Other carbon sources, except galactose and glucose, preferentially metabolized by $L$. rhamnosus ATCC ${ }^{\oplus} 9595^{\text {TM }}$ strain were lactose and mannose. These data are important due to the fact that substantial quantities of galactose and mannose are found in the mammal's intestinal tract. On the other hand microbial lactose metabolism is helpful for people with lactose intolerance. On sucrose, ribose, maltose and arabinose biomass accumulation was less compared with other carbon sources. The obtained data are in accordance with the ones reported by Ceapa et all [20].

The highest growth values $\left(O D_{600 \mathrm{~mm}} 0.465\right)$ was obtained on galactose after $15 \mathrm{~h}$ of incubation. In the case of most carbon sources (except arabinose and ribose) the logarithmic growth phase started after $3 \mathrm{~h}$ and ended after $15 \mathrm{~h}$ of incubation (fig. 1).

Lactococcus group is heterogeneous with respect to specific requirements for nutrients, lactococcal species being limited on various metabolic pathways. Strains belonging to this genus are the most important organisms in the manufacture of fermented dairy products especially cheese, inducing milk acidification and coagulation [21, 22].

Differentreports cited in scientific literature mention that among $L A B$, maltose fermentation has been studied most extensively in lactococci [23].

Our data collected during the evaluation of $L$. lactis 28 growth (fig. 2) revealed that fructose and maltose are the best metabolized carbon sources compared to glucose, used as control, which correlates with the existent data as mentioned above. Other sugars, such as lactose and sucrose can be used as carbon substrates by the analyzed $L$. lactis strain. The maximum biomass accumulation was

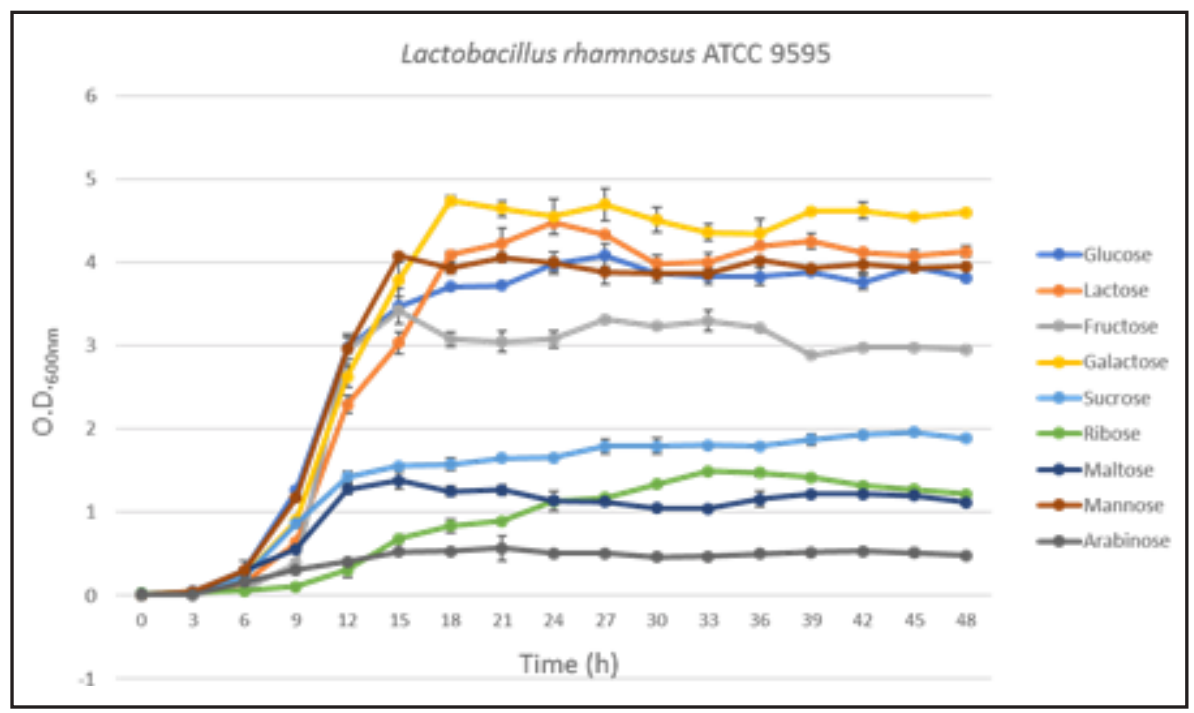

Fig. 1. Growth of L.rhamnosus ATCC ${ }^{\circledR}$ $9595^{\mathrm{TM}}$ on different carbon sources 


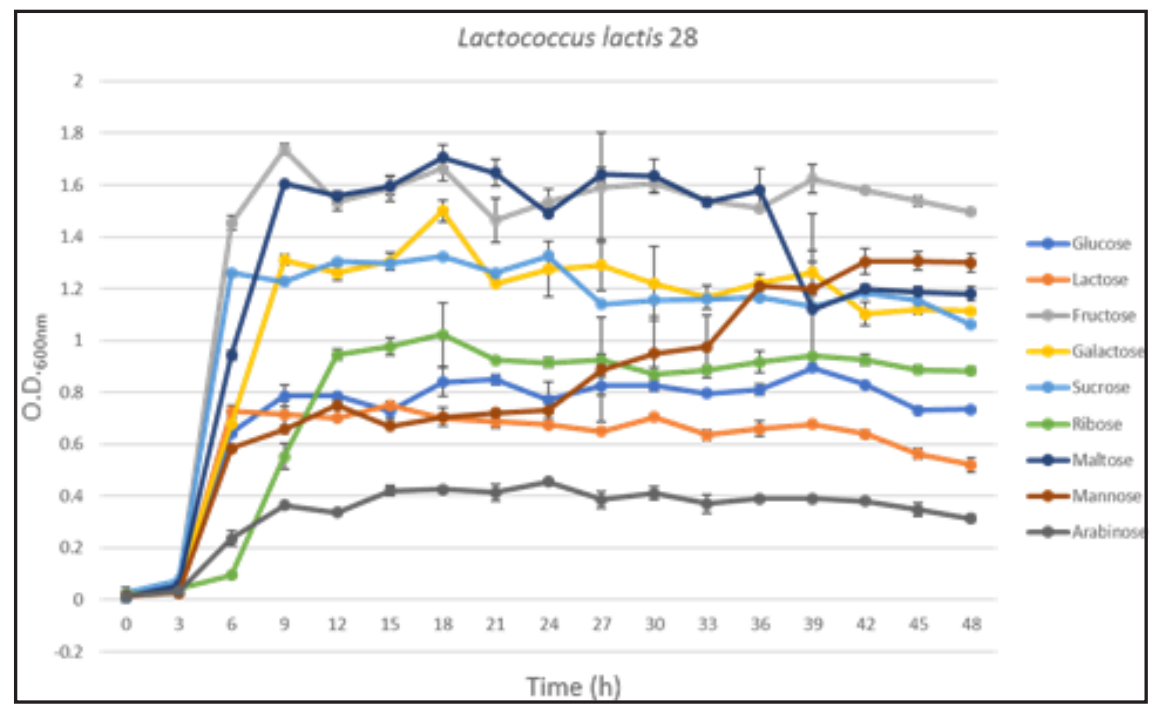

Fig. 2. Growth of L. lactis 28 on different carbon sources

obtained after incubation for $18 \mathrm{~h}$ using maltose as carbon source (OD 1.705$)$.

$P$. acidilactic $i$ is one of the important $L A B$ strains widely used in the food industry (fermented vegetables, dairy, meat, s.o.), being also commonly found as one of the normal microbiota of the gastrointestinal tract $[24,25]$.

The growth rate of $P$. acidilactici ATCC ${ }^{\circledR} 8042^{\text {TM }}$ was increased in the presence of sucrose and maltose, the strain utilizing these sugars preferentially as sources of carbohydrates, compared with glucose (fig. 3). Sucrose is an abundant and inexpensive substrate for industrial biotechnology processes. The mechanism of sucrose fermentation in LAB strains is mediated by a permease system, initiated by the cleavage of the sugar, by sucrose hydrolase, into glucose and fructose, which enter the major pathways [26]. In case of these two carbon sources the strain presented on accelerated growth compared with other carbon sources. The strain metabolizes also with good rates lactose, fructose and mannose.The logarithmic growth phase for maltose, sucrose, glucose, lactose and mannose, was between $3 \mathrm{~h}$ and $9 \mathrm{~h}$ of incubation with a maximum $O D$ 2.61. The results are comparable with other reported data [27].

The Streptococcus genus is one of a great medical importance because includes commensal species (respiratory and digestive tract) and pathogenic strains. Despite this fact, some species, such as $S$. thermophilus have also an enormous significance to the food industry, as it is used world wide as a yoghurt starter and cheese manufacture $[28,29]$. S. thermophilus, as all the other LAB strains is considered to be a fastidious microorganism, with numerous nutritional requirements.

Our study results highlighted that maltose is the primary source of carbon and energy preferentially metabolized by S. salivarius subsp. thermophilus ATCC ${ }^{\otimes} 19258^{\text {TM }}$ as it is presented in figure 4 . The analyzed species utilize also
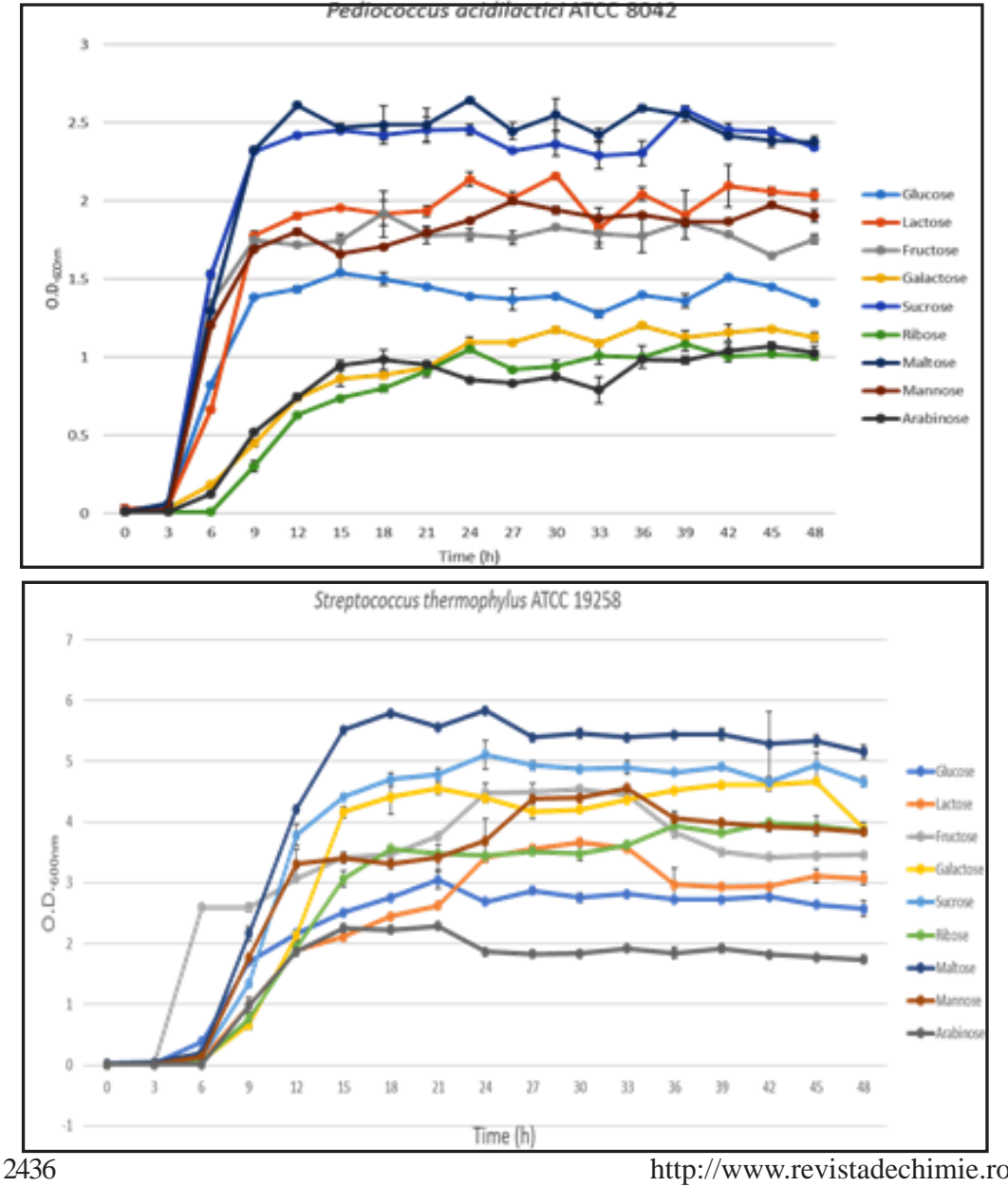

Fig. 3. Growth of $P$. acidilactici $\mathrm{ATCC}^{\circledR} 8042^{\mathrm{TM}}$ on different carbon sources

Fig. 4. Growth curves graphic of S. salivarius subsp. thermophilus ATCC ${ }^{\circledR} 19258^{\mathrm{TM}}$ 


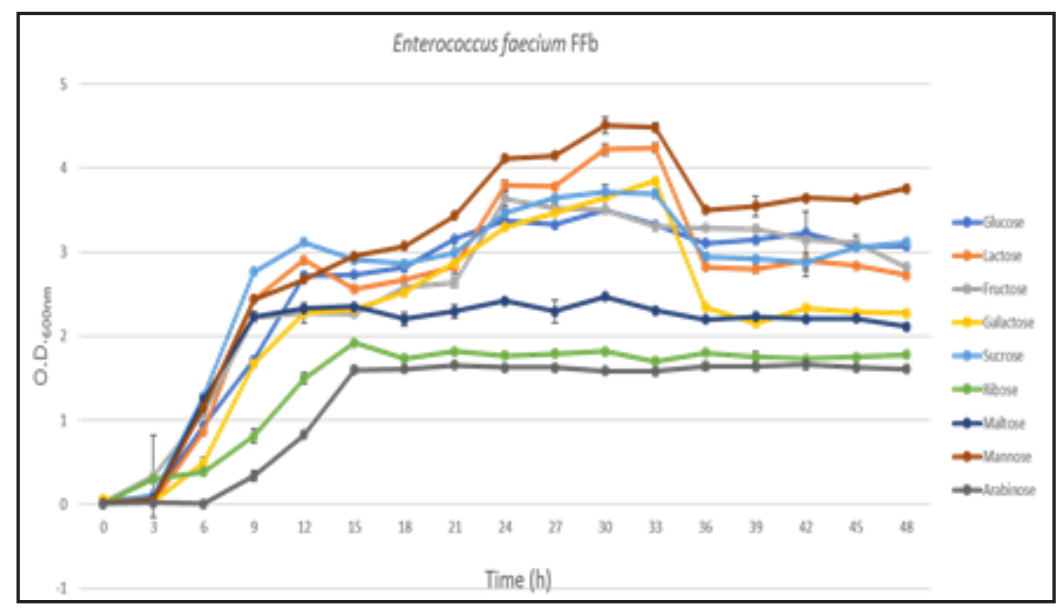

Fig. 5. Growth of $E$. faecium FFb CMGB L-18 on different carbon sources

other sugars, such as sucrose or galactose achieving a good biomass yield. Of all the microbial strains analyzed $S$. salivarius subsp. thermophilusATCC ${ }^{\circledR} 19258^{\mathrm{TM}}$ exhibited the highest rate of growth on all analyzed carbon sources. For most carbon sources the logarithmic growth phase was between $6 \mathrm{~h}$ and $18 \mathrm{~h}$ with a maximum $O D_{600 \mathrm{~nm}} 5.8$ on maltose after $18 \mathrm{~h}$ of incubation.

Enterococci are extensively studied as potential probiotics candidate, due to their capacity to survive, compete and adhere to epithelial cells of the human gastrointestinal tract.

Species belonging to this genus are normal inhabitants of the human gut, but there are also strains suitable as starter cultures for food industry processes, playing an important role in the development of products' flavor and other organoleptic characteristics of various fermented foods $[30,31]$.

Analysis of the growth curves of $E$. faecium $\mathrm{FFb} C M G B$ $L-18$ revealed that this strain prefers to use mannose as carbon substrate (fig. 5), this monosaccharide being converted into glucose for catabolic processes.

Also, our data revealed that other sugars, such as lactose or sucrose can be metabolized by $E$. faecium studied strain with a good growth yield. Generally, all tested carbon components used could sustain the growth of $E$. faecium FFb CMGB L-18, but at different rates. The logarithmic phase was between $3 \mathrm{~h}$ and $12 \mathrm{~h}$ excepting arabinose and ribose for which logarithmic phase was between $6 \mathrm{~h}$ and $15 \mathrm{~h}$.

\section{Conclusions}

Our experimental data presented in this paper revealed specific carbon sources requirements for each analyzed strains of different genera.

Among carbon sources, beside glucose, also maltose, mannose and galactose are found to be preferred; all analyzed strains showed a highly biomass accumulation on medium containing these sugars. This is an important aspect highlighting that some carbon sources, other than glucose found in standard MRS media, can be used by the evaluated LAB strains.

Arabinose was the only carbon source which could not support growth of any $L A B$ strains.

Also, most of the tested strains entered inexponential phase after 3 to 6 hours of incubation in optimal conditions, depending on the carbon source, respectively, activation of a specific metabolic pathway. Some of the strains, e.g. $E$. faecium FFb CMGB L-18, continued to consume the residual sugars, displaying for some carbon sources an atypical growth curve, with two exponential phases. A higher biomass accumulation for all tested carbon sources was observed in the case of L. rhamnosus ATCC ${ }^{\circledR} 9595^{\mathrm{TM}}$,
S. salivarius subsp. thermophilus ATCC ${ }^{\circledR} 19258^{\mathrm{TM}}$ and $E$. faecium FFb CMGB L-18strains compared to $P$. acidilactici ATCC $^{\circledR} 8042^{\mathrm{TM}}$ and L. lactis 28 strains.

The results of the present study revealed that the nutritional requirements of $L A B$ strains are different and complex between strains belonging to different genera and helped us to select the best growth media components for further studies.

\section{References}

1.HAYEK, S.A., IBRAHIM, S.A., Food Nutr. Sci., 4, nr. 11, 2013,p.73. 2.VENKADESAN, D., SUMATHI, V., Int. J. Appl. Res.,1, nr. 11, 2015, p. 970.

3.PELINESCU, D.R., SASARMAN, E., CHIFIRIUC, M.C., STOICA, I., NOHIT, A.M., AVRAM, I., SERBANCEA, F., DIMOV, T.V., Rom.Biotechnol. Lett, 14, nr. 2, 2009, p.4225.

4.PAPAGIANNI, M., Comput. Struct.Biotechnol. J.,3, nr.4, 2012, p.e201210003.

5.VAN MARIS, A.J., KONINGS, W.N., VAN DIJ KEN, J.P., PRONK, J.T., Metab. Eng. 6, nr. 4, 2004, p. 245.

6.ABUBAKR, M.A., AL-ADIWISH, W.M., Int. J . Microbiol. Biotechnol.2, nr. 2, 2017, p.58.

7.GAENZLE, M.G., Curr. Opin. Food Sci., 2, 2015, p.106.

8.VAN NIEL, E.W.J., HAHN-HÄGERDAL, B., Appl. Microbiol. Biotechnol., 52, nr. 5, 1999, p.617.

9.LAHTINEN, S., OUWEHAND, A.C., SALMINEN, S., VON WRIGHT, A. eds., 2011. Lactic acid bacteria: microbiological and functional aspects. CRC Press.

10.VASSU, T., SMARANDACHE, D., STOICA, I., SASARMAN, E., FOLOGEA, D., MUSAT, F., CSUTAK, O., NOHIT, A.M., IFTIME, O., GHERASIM, R., Rom.Biotechnol. Lett,7, 2002, p.585.

11.MOULAY, M., BENLAHCEN, K., AGGAD, H., KIHAL, M., Advances in Environmental Biology, 7, nr. 6, 2013, p.999.

12.DE VUYST, L., Food Technol. Biotechnol., 38, nr. 2, 2000, p.105.

13.PARADA, J.L., CARON, C.R., MEDEIROS, A.B.P., SOCCOL, C.R., Braz. Arch. Biol. Technol., 50, nr. 3, 2007, p.512.

14.GROSU-TUDOR S.S, STANCU M.M., PELINESCU D., ZAMFIR M., World J Microbiol. Biotechnol. 30, 2014, p. 2459.

15.RUSU, E., SARBU, I., CRISTESCU, C., COCULESCU, B., PETRUT, S., MOLDOVAN, H., MURESAN, A., VASSU, T., PELINESCU, D., Rev. Chim. (Bucharest), 67, no. 12, 2016, p.2417.

16.RUSU, E., MOLDOVAN, CA., MITACHE, M.M., NICULAE, M., POPESCU, G.G., NEMES, R.M., Rev. Chim (Bucharest), 70, no.1, 2019, p.128-132

17.SARBU, I., VASSU, T., CHIFIRIUC, M.C., BUCUR, M., STOICA, I., PETRUT, S., RUSU, E., MOLDOVAN, H., PELINESCU, D., Rev. Chim. (Bucharest), 68, no.12, 2017, p. 3015-3021

18.SCHILLINGER, U., HOLZAPFEL, W.H., BJ ORKROTH, K.J., Food spoilage microorganisms, Woodhead Publishing, 2006, p. 541.

19.SALVETTI, E., TORRIANI, S., FELIS, G.E., Probiotics Antimicrob. Proteins, 4, nr. 4, 2012, p. 217. 
20.CEAPA C., LAMBERT J ., VAN LIMPT K., WELS M., SMOKVINA T., KNOL J., KLEEREBEZEM M., Appl. Environ. Microbiol. Jul., 81, nr. 16, 2015, p. 5458.

21.SAMARZIJ A, D., ANTUNAC, N., LUKAC HAVRANEK, J., Mljekarstvo: casopis za unaprjedenje proizvodnje i prerade mlijeka, 51, nr. 1, 2001, p.35.

22.TAN-A-RAM, P., CARDOSO, T., DAVERAN-MINGOT, M.L., KANCHANATAWEE, S., LOUBIERE, P., GIRBAL L., COCAIGNBOUSQUET, M., Appl. Environ. Microbiol., 77, nr. 3, 2011, p. 739.

23.MANZOOR, A., QAZI, J.I., UL HAQ, I., MUKHTAR, H., RASOOL, A.J . Biol. Eng., 11, nr. 1, 2017, p.17.

24.HALIM, M., MUSTAFA, N.A.M., OTHMAN, M., WASOH, H., KAPRI, M.R., ARIFF, A.B., LWT-Food Sci. Technol., 81, 2017, p. 210.

25.OTHMAN, M., ARIFF, A.B., WASOH, H., KAPRI, M.R., HALIM, M., AMB Express, 7, nr. 1, 2017, p. 215.
26.LEORICY, W., UGARTE, B., KAROLY, A., Fems Yeast Research. Oxford Univ Press, 16, 2016.

27.ALTUNTAS, E. G., COSANSU, S., AYHAN, K., Int. J. Food Microbiol., 141, nr. 1-2, 2010, p. 28.

28.HARDIE, J.M., WHILEY, R.A., The genera of lactic acid bacteria, Springer, Boston, MA., 1995, p. 55.

29.TOIT, M.D., HUCH, M., CHO, G.S., FRANZ, C.M., The genus Streptococcus. Lactic Acid Bacteria: Biodiversity and Taxonomy, 2014, p.457.

30.HANCHI, H., MOTTAWEA, W., SEBEI, K., HAMMAMI, R., Front. Microbiol., 9, nr. 1791, 2018, p. 1.

FRANZ, C.M., HUCH, M., ABRIOUEL, H., HOLZAPFEL, W., GALVEZ, A., Int. J. Food Microbiol., 151, nr. 2, 2011, p.125

Manuscript received: 20.01 .2019 